Аналіз стану та тенденцій розвитку зовнішньої торгівлі в Дніпропетровській області: виклики та можливості для сталого регіонального зростання

\author{
Ольга Матвеєва, Лілія Шевченко, Дніпропетровський регіональний інститут \\ державного управління Національної академії державного управління при \\ Президентові України
}

У статті проведено оцінку стану та здійснено аналіз поточних тенденцій розвитку вітчизняної зовнішньої торгівлі на прикладі Дніпропетровської області. Аналіз проведено крізь призму виявлення викликів та можливостей для регіону, що відкриває зовнішня торгівля. Вплив зовнішньої торгівлі регіону на його міжнародні економічні відносини в умовах європейської інтеграції України та розгортання глобалізаційних процесів $\epsilon$ вкрай значимим. Дніпропетровська область входить до числа провідних експортерів та, за підсумками 2018 р., посідає друге місце за обсягами експорту товарів серед регіонів України. Тому вибір регіону для проведення дослідження обумовлено важливістю розвитку міжнародної торгівлі на його теренах для посилення позицій міжнародної конкурентоспроможності України. У статті визначено та проаналізовано показники зовнішньої торгівлі Дніпропетровської області з країнами світу, а також економічний результат та ефект такого впливу.

Основну увагу приділено оцінці та аналізу динаміки змін у структурі експорту та імпорту товарів. Зокрема, проаналізовано тенденцію зменшення обсягів експорту послуг Дніпропетровської області до країн ЄС протягом 2014-2017 pp., що є негативною тенденцію, збільшення цього показника у 2018 p.

Загалом встановлено збільшення кількості підприємств області, що здійснювали зовнішньоторговельну діяльність товарами. Акцентовано увагу на товарній структурі експорту області. Ї̈̈ складають чорні метали (46,3 \%) та руди, шлак і зола (23,2 \%). Основу товарної структури імпорту області складають палива мінеральні; нафта та продукти ії перегонки (30,3%), машини, обладнання та механізми; електротехнічне обладнання $(14,4$ \%), продукція хімічної та пов'язаних з нею галузей промисловості (11,3\%) та недорогоцінні метали й вироби 3 них (11 \%). Динаміка зміни структури експорту свідчить про певну сповільненість процесу переходу до «економіки нового типу», що має базуватися не на прямому споживанні ресурсів, а на інноваціях, знаннях і технологіях, їх застосуванні у виробництві товарної продукції та наданні послуг.

Стаття є підсумковим оглядом ситуації у сфері зовнішньої торгівлі області, здійсненим у межах завдання щодо підготовки Стратегії розвитку Дніпропетровської області на період до 2027 p.

Ключові слова: зовнішня торгівля, експорт, імпорт, сальдо, міжнародні економічні відносини, економічний розвиток, Дніпропетровська область

\title{
Analysis of the situation and trends in foreign trade of Dnipropetrovsk region: challenges and opportunities for the sustainable regional growth
}

\section{Olga Matveieva, Lilia Shevchenko, Dnipropetrovsk regional institute for public administration National academy for public administration under the President of Ukraine}

The article assesses the situation and analyzes the current trends in the development of domestic foreign trade through the case of Dnipropetrovsk region. The analysis is conducted through the lens of identifying challenges and opportunities for the region that are opened up by foreign trade. The impact of the region's foreign trade on its international economic relations in the context of Ukraine's European integration and the deployment of globalization processes is significant. Dnipropetrovsk region is one of the leading exporters and, according to the results of 2018, ranks second place among the regions of Ukraine by the export of goods. Therefore, choosing the region for the study is determined by the importance of the development of international trade in its territories to strengthen the position of Ukraine's international competitiveness. The article identifies and analyzes the indicators of foreign trade of the Dnepropetrovsk region with the world countries, as well as the economic result and effect of it's influence. The focus is put on assessing and analyzing the dynamics of changes in the structure of export and import of goods. 
In particular, the tendency of decrease in export of services of Dnepropetrovsk region to the EU countries during 2014-2017 is analyzed as a negative trend. Positive trend visualizes through increasing of this indicator in 2018. Overall, the increase of the number of regional enterprises engaged in the foreign trade of goods was shown. Emphasis is placed on the commodity structure of export. It is composed of ferrous metals $(46.3 \%)$ and ores, slag and ash (23.2\%). The basis of the commodity structure of import is mineral fuels; oil and its distillation products (30.3\%), machinery, equipment and mechanisms; electrical equipment (14.4\%), chemical products and related industries (11.3\%), and precious metals (11\%). The dynamics of the change in the export structure indicates a certain slowdown in the process of transition to a "new type economy', which should be based not on direct consumption of resources, but on innovation, knowledge and technology, their application in products and services production.

The article is a summary of the situation in the field of foreign trade of the region, which is carried out in the framework of the task of drafting the Strategy of development of Dnipropetrovsk region for the period until 2027.

Keywords: foreign trade, export, import, balance, international economic relations, economic development, Dnipropetrovsk region

\section{Анализ состояния и тенденций развития внешней торговли в Днепропетровской области: вызовы и возможности для устойчивого регионального роста}

\section{Ольга Матвеева, Лилия Шевченко, Днепропетровский региональный институт государственного управления Национальной академии государственного управления при Президенте Украины}

В статье проведена оценка состояния и осуществлен анализ текущих тенденций развития отечественной внешней торговли на примере Днепропетровской области. Анализ проведен сквозь призму выявления вызовов и возможностей для региона, открывает внешняя торговля. Влияние внешней торговли региона в его международные экономические отношения в условиях европейской интеграции Украины и развертывания глобализационных процессов является крайне значимым. Днепропетровская область входит в число ведущих экспортеров и, по итогам 2018, занимает второе место по объемам экспорта товаров числе регионов Украины. Поэтому выбор региона для проведения исследования обусловлено важностью развития международной торговли на его территории для усиления позиций международной конкурентоспособности Украины. В статье определены и проанализированы показатели внешней торговли Днепропетровской области со странами мира, а также экономический результат и эффект такого воздействия.

Основное внимание уделено оценке и анализу динамики изменений в структуре экспорта и импорта товаров. В частности, проанализированы тенденции уменьшения объемов экспорта услуг Днепропетровской области в страны ЕС в течение 2014-2017 г., Что является негативной тенденции, увеличение этого показателя в 2018

Всего установлено увеличение количества предприятий области, которые осуществляли внешнеторговую деятельность товарами. Акцентировано внимание на товарной структуре экспорта области. Ее составляют черные металлы $(46,3 \%)$ и руды, шлак и зола $(23,2 \%)$. Основу товарной структуры импорта области составляют топлива минеральные; нефть и продукты ее перегонки (30,3\%), машины, оборудование и механизмы; электротехническое оборудование $(14,4 \%)$, продукция химической и связанных с ней отраслей промышленности $(11,3 \%)$ и недрагоценные металлы и изделия из них (11\%). Динамика изменения структуры экспорта свидетельствует об определенной замедленность процесса перехода к «экономике нового типа», что должно базироваться не в прямом потреблении ресурсов, а на инновациях, знаниях и технологиях, их применении в производстве товарной продукции и оказании услуг.

Статья является итоговым обзором ситуации в сфере внешней торговли области, осуществленным в пределах задачи по подготовке Стратегии развития Днепропетровской области на период до 2027 г.

Ключевые слова: внешняя торговля, экспорт, импорт, сальдо, международные экономические отношения, экономическое развитие, Днепропетровская область 


\section{Постановка проблеми}

7 овнішня торгівля є вагомим чинником економічного успіху держави

у процесах взаємодії національної економічної системи зі світовою, виступаючи центральною ланкою міжнародних економічних відносин. Вони, своєю чергою, мають велике значення для прогресивного розвитку національної економіки в глобалізованому середовищі. Тому дослідження регіонального виміру зовнішньої торгівлі як основного каналу впливу України на світогосподарські зв'язки та вимірювання його результатів і ефектів нині набувають важливого наукового та практичного значення.

\section{Аналіз досліджень і публікацій}

Проблемам розвитку зовнішньої торгівлі України та їі регіонів присвячено роботи багатьох українських та зарубіжних вчених: В. Балассу, В. Будкіна, Т. Власюк, В. Гейця, Е. Грайпла, О. Гребельника, Д. Зайцева, А. Касич, В. Кравцова, А. Мазаракі, В. Мовчан, М. Портера, С. Смалвуда, Дж. Стігліца, А. Філіпенка, С. Фішера, Л. Ярош-Дмитренко та інших. Проте, незважаючи на численні дослідження, існує постійна потреба у здійсненні моніторингу ситуації в даній сфері, що обумовлює актуальність пропонованого дослідження.

Метою статті $\epsilon$ аналіз стану i виявлення актуальних тенденцій розвитку зовнішньоторговельної діяльності Дніпропетровської області України.

\section{Виклад основного матеріалу}

Зовнішньоторговельні зв'язки є важливим індикатором економічного розвитку країни та іiі регіонів. В умовах глобалізації значення зовнішньої торгівлі суттєво зростає, оскільки локальні економічні системи стають все більш відкритими і вразливими до впливів зовнішнього середовища.

Дніпропетровська область входить до числа провідних експортерів та, за підсумками 2018 р., посідає друге місце за обсягами експорту товарів серед регіонів України. У 2018 р. продовжувалась минулорічна тенденція нарощування зовнішньоторговельного обігу. За даними Державної служби статистики України у 2018 р., обсяги експорту товарів Дніпропетровської області становили 7 722,6 млн дол. США (109,5 \% від рівня 2017 р.), що складає 16,3\% від загального показника в Україні. Обсяги імпорту товарів склали 5 264,9 млн дол. США (114,2 \% від рівня 2017 р.). За таким показником Дніпропетровська область посідає друге місце в Україні (9,2 \% від загального обсягу імпорту товарів в Україні). Сальдо зовнішньої торгівлі товарами у 2018 р. було додатним, становило 2457,7 млн дол. США.

Аналіз динаміки географічної структури експорту товарів свідчить про те, що відбувається стале збільшення обсягів експорту до країн Європи, зокрема СС (28), протягом 2015-2018 pр. (табл. 1).

Аналогічною є тенденція щодо країн АмеТаблиия 1 Динаміка експорту товарів Дніпропетровської області до країн світу у 2014-2018 рр., млн дол. США

\begin{tabular}{|c|c|c|c|c|c|c|c|}
\hline \multirow{2}{*}{ Ptr. II } & \multicolumn{7}{|c|}{ Km } \\
\hline & Pasin & Ipoine CHD & Frping & Ipoine (AB) & Amin & An: in & Atring \\
\hline 2014 & B763,9 & 2525,0 & 1502,7 & 17549 & $\overline{3288,3}$ & 993,1 & 154,4 \\
\hline 2015 & $639 \%, 0$ & J1E7,4 & 1402,2 & 1347,3 & 2457,7 & 1184,9 & 165,2 \\
\hline 2016 & $5: 64, B$ & BZR,7 & 1724,0 & 1653,5 & 2063,8 & 1057,3 & 183,4 \\
\hline 2017 & $7052, \mathrm{~B}$ & 932,6 & 2404,4 & 23145 & 298,0 & $102 \pi, 3$ & 394,0 \\
\hline 2018 & $T / 2,6$ & 963,2 & 2906,5 & 27465 & $\overline{2224,6}$ & 1176,1 & 4275 \\
\hline
\end{tabular}

рики, яка спостерігається протягом 2014-2018 pp. Натомість, за даними Головного управління статистики у Дніпропетровської області у 2014-2016 рр., суттєво зменшилися обсяги експорту товарів до країн СНД, але, починаючи з 2017 р., обсяги поступово зростають.

Суттєві експортні поставки товарів се- ред країн-членів СС у 2018 р. здійснювалися до Польщі, Словаччини, Угорщини, Чехії, Румунії, Італії. Серед інших країн світу найбільше експортовано товарів до Китаю, Туреччини, Російської Федерації, Сгипту та Алжиру.

Аналіз динаміки географічної струк- 
тури імпорту товарів, що базується на даних Головного управління статистики у Дніпропетровської області, свідчить про те, що протягом 2014-2015 рр. відбувалося зменшення обсягів імпорту з країн СНД, починаючи 32016 р., спостерігається поступове збільшення імпорту (табл. 2).

Щодо країн Свропи спостерігається аб-

Динаміка імпорту товарів Дніпропетровської області з країн світу

Таблиия 2 у 2014-2018 рр., млн дол. США

\begin{tabular}{|c|c|c|c|c|c|c|c|}
\hline \multirow{2}{*}{ Ptrix } & \multicolumn{7}{|c|}{ 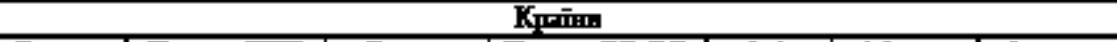 } \\
\hline & Pangr & Frīin chd & Girom & Krin: ECQ⿻日木) & Am & Ari:-1a & At \\
\hline 2014 & 46363 & 12812 & 1813,3 & 1751,1 & 1057Д & 127,7 & 3305 \\
\hline 2015 & $3271, \mathrm{~B}$ & 1013,6 & 11709 & 113:2 & 7153 & 1292 & 2163 \\
\hline 2016 & 34000 & 1075,9 & 124:1 & 1214,4 & 7.33 & 1052 & 22,1 \\
\hline 2017 & 16320 & 15520 & 1521,0 & 1493,3 & $\log 64$ & 193,0 & 305,0 \\
\hline 2018 & 53160 & 1877 & 1673 & $15 \times 3$ & $1315 \mathrm{~B}$ & 1564 & 330,0 \\
\hline
\end{tabular}

солютне повторення тенденції динаміки експорту, а саме: у 2014-2015 рр. спостерігалося зменшення обсягів імпорту 3 країн Європи, зокрема країн СС (28), але з 2016 р. відбувається поступове нарощу- вання обсягів. Динаміка зовнішньої торгівлі товарами Дніпропетровської області 3 країнами СС (28) і країнами СНД представлена на рис. 1.

Серед країн СС найвагоміші імпортні
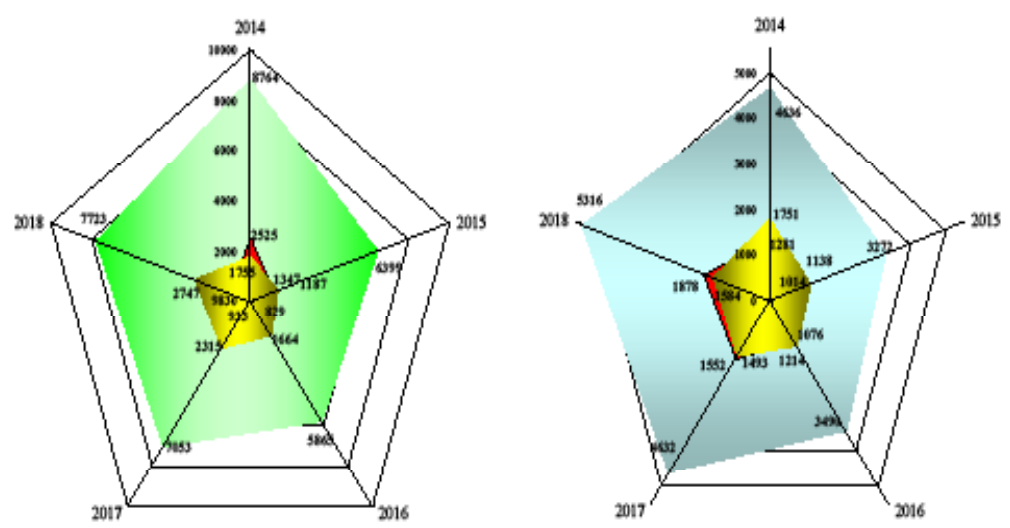

Рис 1. Динаміке зовнішньої тергівлі тыварами Дніпропетровкько̄ області з країнами еС (28) і країнами СНД у 2014-2018 рр., млн дол. США

\footnotetext{
II Exспорт товарів

= Imорт товарів
}

$\square$ Eкспорт товарів жраїнн СНД

口 Іпторт товарів мраїнн СНД
II Eкспорт товарів країни $Є C$ (28)

"1 Імпорт товарів мраӥни $€ C$ (28) надходження товарів у 2018 р. здійснювалися з Німеччини, Італії, Польщі, Словаччини, Франції. Серед інших країн світу найбільші імпортні поставки товарів надходили з Російської Федерації, Китаю та США.

Протягом 2014-2017 рр. спостерігалося збільшення кількості підприємств, що здійснювали зовнішньоторговельну діяльність товарами (у 2017 р. експортували товари 1233 підприємств, імпортували 2248 підприємств [3]). Основу товарної структури експорту області у 2017 р. складали чорні метали (46,3 \% від загального обсягу) та руди, шлак і зола (23,2 \%). Основу товарної структури імпорту області у 2017 р. складали палива мінеральні; нафта та продукти іiі перегонки (30,3% від загального обсягу), машини, обладнання та механізми; електротехнічне обладнання $(14,4$ \%), продукція хімічної та пов'язаних 3 нею галузей промисловості (11,3 \%) та недорогоцінні метали та вироби 3 них (11 \%) [3]. Найактивніше здійснювали зовнішню торгівлю товарами підприємства у містах: Кривий Ріг, Дніпро, Кам'янське, Нікополь та Павлоград; районах: Дніпровський, 
Верхньодніпровський, Нікопольський, Новомосковський, Солонянський.

За даними Державної служби статистики України, у 2018 р. обсяги експорту послуг становили 134,4 млн дол. США (107,5 \% від рівня 2017 р.). За цим показником Дніпропетровська область посіла 8-е місце серед регіонів України, а питома вага становить 1,1 \% від загального показника в Україні. Обсяги імпорту послуг становили 230,3 млн дол. США (100,6 \% від рівня 2017 р.). За цим по- казником область посіла 2-е місце серед регіонів України, питома вага становить 4,0 \% від загального показника в Україні. Сальдо зовнішньої торгівлі послугами у 2018 р. було від'ємним (-95,9 млн дол. США).

Аналіз динаміки географічної структури [5] свідчить про зменшення обсягів експорту послуг до країн СНД у 2014-2015 рр. та поступове збільшення у 2016-2017 pр. (табл. 3).

Протягом 2014 - 2017 рр. відбувалося

Динаміка експорту послуг Дніпропетровської області до країн світу

Таблиия 3 у 2014-2018 рр., млн дол. США

\begin{tabular}{|c|c|c|c|c|c|c|c|}
\hline \multirow{2}{*}{ Per } & \multicolumn{7}{|c|}{ K' } \\
\hline & Pastat & Kmin CHJ & Em:m & 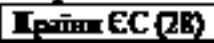 & Amin & Ab, IIIII & $A=10$ \\
\hline 2014 & $\overline{376,8}$ & BS, & 97,5 & 1893 & 91,0 & 2,1 & $\overline{\mathrm{B}, \overline{\mathrm{B}}}$ \\
\hline 2015 & 2944 & 352 & Ss, 4 & 98,1 & 51,1 & 2,1 & 99,1 \\
\hline 2016 & 1756 & 254 & 49,4 & 569 & 19,6 & 42 & 76,8 \\
\hline 2017 & 125,0 & $\overline{27,6}$ & 472 & 54,7 & 199 & 2,9 & $\overline{27,2}$ \\
\hline 2018 & 1373 & 33,5 & 48,4 & $57, \mathrm{~B}$ & 2,3 & 4,0 & 253 \\
\hline
\end{tabular}

зменшення обсягів експорту послугдо країн $\epsilon \mathrm{C}$, що є негативною тенденцію. Лише у 2018 р. спостерігається збільшення цього показника.

У структурі експорту послуг у 2017 р. переважали транспортні послуги (33,2 \% від загального обсягу експорту), у сфері телекомунікації, комп'ютерні та інформаційні (32,8 \%) й ділові (13,5\%).

Обсяги імпорту послуг 3 країн
СНД майже у 5 разів зменшилися у період 2014-2018 pp., незначне збільшення показника спостерігалося лише у 2017 p. порівняно 3 попереднім роком. Обсяги імпорту послуг 3 країн ЄС зменшилися у період 2014-2018 pp., але динаміка за роками є нестабільною (табл. 4).

Динаміка зовнішньої торгівлі послугами Дніпропетровської області з країнами СС

Таблиия 4

Динаміка імпорту послуг Дніпропетровської області з країн світу у 2014-2018 рр., млн дол. США

\begin{tabular}{|c|c|c|c|c|c|c|c|}
\hline \multirow{2}{*}{ Ptrix } & \multicolumn{7}{|c|}{ 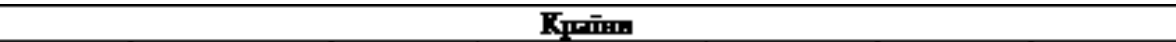 } \\
\hline & Panox & Ipiin CHI & Exingm & 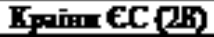 & Amin & Alj I & $A=10$ \\
\hline 2014 & 37,4 & 56,9 & 2019 & 22,2 & 42,6 & 0,3 & 60,3 \\
\hline 2015 & 402,1 & 24,1 & 3053 & 315,1 & 25,4 & 03 & 166 \\
\hline 2016 & 3150 & 17,7 & 2105 & 245 & $\mathbf{5 2 2}$ & 04 & 342 \\
\hline 2017 & 22159 & 19,0 & 148,9 & 173,3 & 52,1 & 0,4 & B,5 \\
\hline 2018 & 2317 & 110 & 174,0 & 1875 & 378 & 01 & BB \\
\hline
\end{tabular}

(28) і країнами СНД представлена на рис. 2.

Основу структури імпорту послуг області у 2017 р. складали ділові $(34,4$ \% від загального обсягу імпорту), роялті та інші послуги, пов'язані з використанням інтелектуальної власності $(31,7$ \%), та транспортні $(17 \%)$.

Значні обсяги експорту-імпорту послуг 


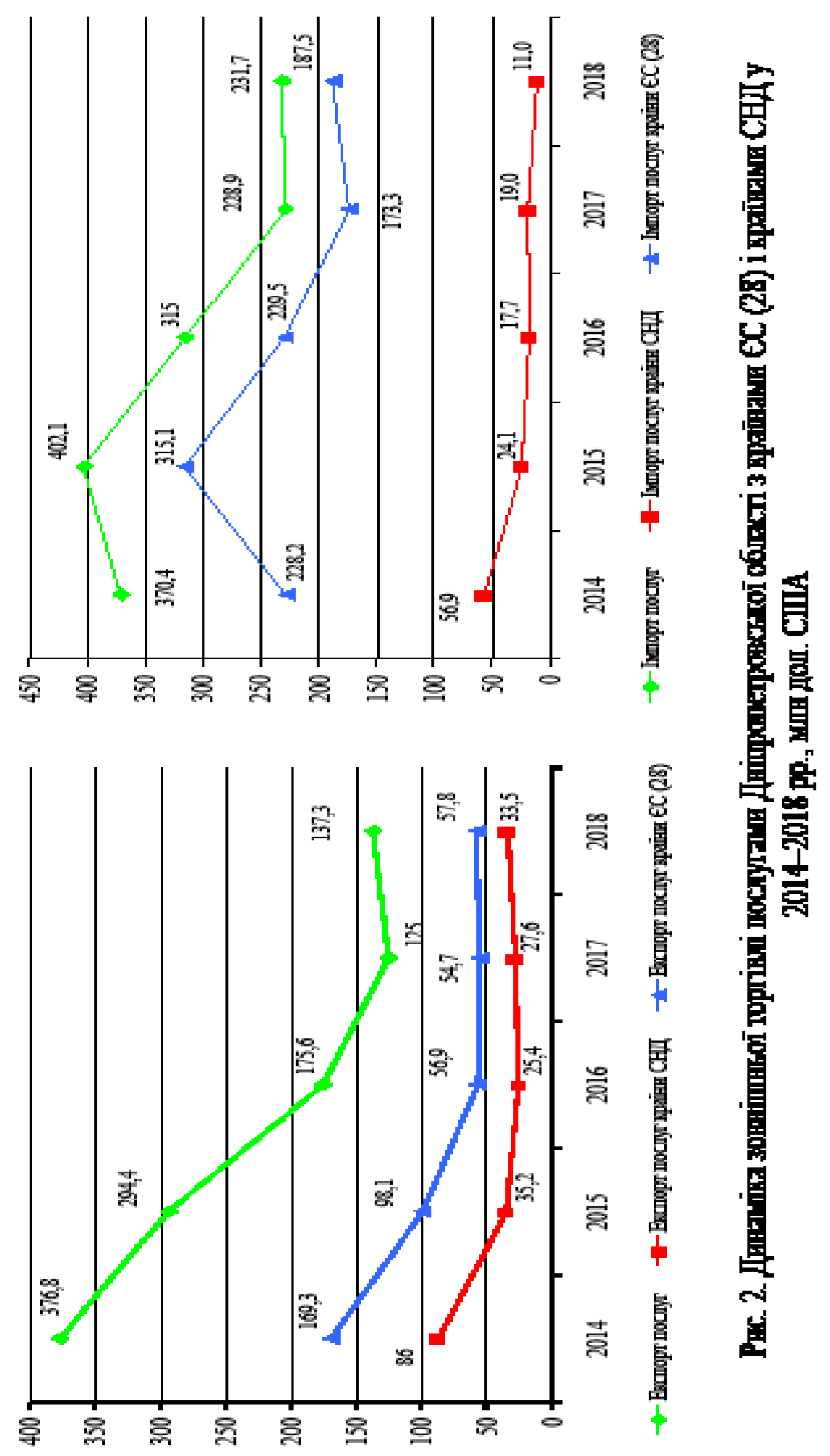


припадали на підприємства міст Дніпро, Кривий Ріг, Кам'янське, Нікополь та Павлоград, районів - Дніпровський, Верхньодніпровський, Синельниківський та Солонянський.

Загалом щодо зовнішньої торгівлі Дніпропетровської області спостерігається низка тенденцій, що містять як позитивні, так і негативні ознаки. Протягом 20142016 рр. зменшувалися обсяги експорту товарів і послуг Дніпропетровської області. Протягом 2017-2018 рр. відбувається поступове збільшення показника, але у 2018 р. досягнуто лише $86 \%$ від рівня 2014 р. (табл. 5).

Обсяги імпорту товарів і послуг Таблиия 5

Зовнішня торгівля товарами і послугами Дніпропетровської області у 2014-2018 pp.

\begin{tabular}{|c|c|c|c|c|c|c|}
\hline \multirow{2}{*}{ It. ram:de } & \multicolumn{6}{|c|}{ Pan } \\
\hline & 2014 & $\mathbf{2 0 1 5}$ & 2016 & 2017 & $\mathbf{X I B}$ & $\mathrm{X} 1 \mathrm{1B} ; 2014, \%$ \\
\hline 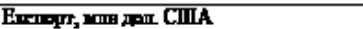 & $9] 40,7$ & 6693,4 & 6040,5 & $7] 7,7$ & 7857,3 & 8,60 \\
\hline 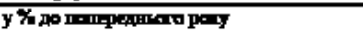 & вд. & 7,2 & 9,2 & $\overline{118,8}$ & $\overline{109,5}$ & - \\
\hline 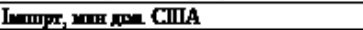 & 5004,6 & 36739 & 3005,0 & $4 B 609$ & 5494,7 & 10,B \\
\hline 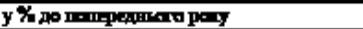 & Ед. & 73,4 & 103,6 & $\mathbf{1 2 7 , \mathbf { s }}$ & 113,0 & - \\
\hline 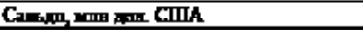 & 4136,1 & 30195 & 2235,5 & 2316,8 & 23626 & - \\
\hline 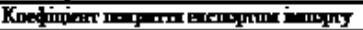 & $1, \mathrm{~B}$ & $\overline{1, B}$ & 1,6 & 1,5 & 1,4 & - \\
\hline 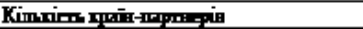 & вд. & $\mathbf{1 4 8}$ & 155 & 157 & I59 & - \\
\hline
\end{tabular}

зменшувалися протягом 2014-2015 рр., але, починаючи 32016 р., цей показник збільшується, зменшуючи при цьому додатне значення сальдо зовнішньої торгівлі (у 2014 р. становило 4136,1 млн дол. США, у 2018 р. становило 2361,8 млн дол. США) (рис. 3). Відповідно, негативною є чітка тенденція до знижен- ня коефіцієнту покриття експортом імпорту (зі значення 1,8 у 2014 р. до 1,4 у 2018 р.) (табл. 5).

Вкрай негативною є тенденція до суттєвого зменшення експорту послуг, зокрема до країн ЄС (28), протягом 2014-2018 рр. (рис. 3).

\section{Висновки}

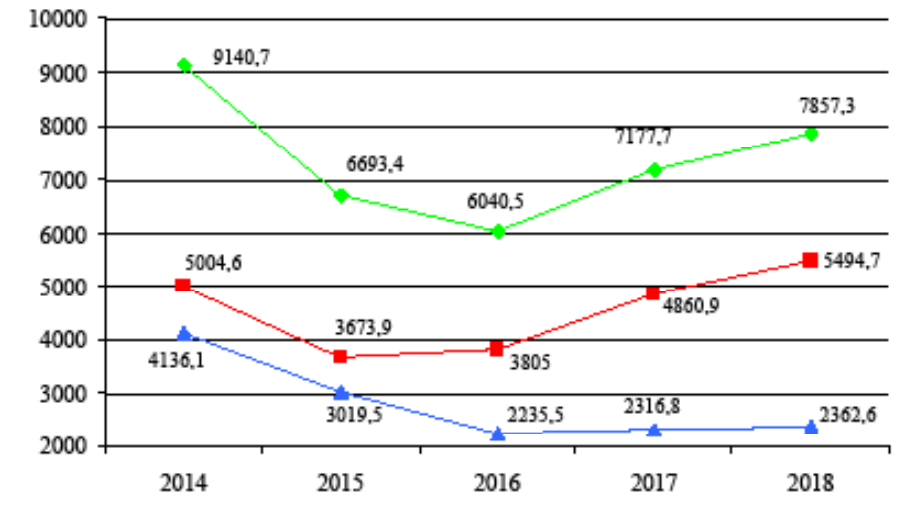

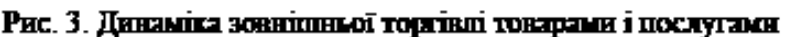
Даїропетровської області у 2014-2018 pp.

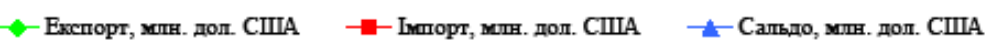

1. Стан зовнішньої торгівлі товарами Дніпропетровської області перебуває у безпосередній залежності від розвитку іï економіки, а також загальнонаціональної економічної та геополітичної ситуації. Зокрема, у періоди економічної кризи суттєво зменшуються обсяги експорту й імпорту товарів та, відповідно, зовнішньоторговельний обіг. Протягом
2014-2016 рр. зменшувалися обсяги експорту товарів і послуг Дніпропетровської області. Протягом 2017-2018 pр. відбувається поступове збільшення показника, але у 2018 р. досягнуто лише $86 \%$ від рівня 2014 р. Обсяги імпорту товарів і послуг зменшувалися протягом 2014-2015 рр., але, починаючи з 2016 р., цей показник зростав, зменшуючи при 
цьому додатне значення сальдо зовнішньої торгівлі

(у 2014 р. становило 4136,1 млн дол. США, у 2018 р. - 2361,8 млн дол. США). Негативною $є$ чітка тенденція до зниження коефіцієнту покриття експортом імпорту (зі значення 1,8 у 2014 р. до 1,4 у 2018 р.). Вкрай негативною є тенденція до суттєвого зменшення експорту послуг, зокрема до країн СС (28), протягом 2014-2018 pp.

2. У товарній структурі експорту переважають товари сировинного походження (палива мінеральні; нафта та продукти іiї перегонки, які склали 30,3% від загального обсягу), що відповідає рівню регіону 3 середніми показниками соціо-еколого-економічного розвитку. Позитивним є зростання частки таких ви- дів продукції, як машини, обладнання та механізми; електротехнічне обладнання, продукція хімічної та пов'язаних 3 нею галузей промисловості, що є свідченням поступової трансформації структури економіки в бік побудови системи, орієнтованої на знання, технології та інновації.

3. Виходячи 3 окресленої ситуації, можна підсумувати, що посилення Дніпропетровщиною обраного геостратегічного торгівельного вектора спіткає підприємства регіону, окрім, вибору нових напрямів і форм зовнішньої торгівлі до пошуку нових ніш діяльності, де вирішальним є забезпечення на основі знань та інновацій таких переваг, які забезпечили би їм можливість займати нові ніші та активно розвиватися в міжнародному конкурентному середовищі.

\section{БІБЛІОГРАФІЧНІ ПОСИЛАННЯ:}

1. Регіональні обсяги зовнішньої торгівлі товарами у 2018 p. URL: http://www.ukrstat.gov.ua/operativ/ operativ2018/zd/oet/oet_u/oet1218_u.htm (дата звернення 01.06.2019).

2. Динаміка географічної структури зовнішньої торгівлі Дніпропетровської області товарами (у 19962018 pp.). URL: http://dneprstat.gov.ua/statinfo \%202015/zed/2018/zed7.pdf (дата звернення 09.06.2019).

3. Зовнішня торгівля Дніпропетровської області товарами та послугами у 2017 році. Статистичний збірник. Дніпро, 2018. 60 с.

4. Регіональні обсяги зовнішньої торгівлі послугами у 2018 p. URL: https://ukrstat.org/uk/operativ/ operativ2018/zd/oep/oep_u/arh_oep2018.html (дата звернення 10.06.2019).

5. Динаміка географічної структури зовнішньої торгівлі Дніпропетровської області послугами (у 19962018 pp.).URL: http://dneprstat.gov.ua/ statinfo\%202015/zed/2018/zed8.pdf (дата звернення 02.06.2019).

6. Статистичний збірник «Регіони України». 2014 рік. Ч. 2. URL: https:/ukrstat.org/uk/druk/publicat/ Arhiv_u/Arch_reg.htm (дата звернення 03.06.2019).

\section{REFERENCES}

1. Rehionalni obsiahy zovnishnoi torhivli tovaramy u $2018 \mathrm{r}$. [Regional level of foreign trade of goods in 2018]. Retrieved from http://www.ukrstat.gov.ua/operativ/operativ2018/zd/oet/oet_u/oet1218_u.htm [in Ukrainian].

2. Dynamika heohrafichnoi struktury zovnishnoi torhivli Dnipropetrovskoi oblasti tovaramy (u 1996 - 2018 rr.) [Dynamics of the geographical structure of foreign trade in the Dnepropetrovsk region of goods (in 1996-2018)]. Retrieved from http://dneprstat.gov.ua/statinfo \%202015/zed/2018/zed7.pdf [in Ukrainian].

3. Zovnishnia torhivlia Dnipropetrovskoi oblasti tovaramy ta posluhamy u 2017 rotsi [Foreign trade of Dnepropetrovsk region with goods and services in 2017]. (2018). Statystychnyi zbirnyk - Statistical collection. Dnipro [in Ukrainian]. 4. Rehionalni obsiahy zovnishnoi torhivli posluhamy u $2018 \mathrm{r}$. [Regional volumes of foreign trade in services in 2018]. Retrieved from https://ukrstat.org/uk/operativ/operativ2018/zd/oep/oep_u/arh_oep2018.html [in Ukrainian].

5. Dynamika heohrafichnoi struktury zovnishnoi torhivli Dnipropetrovskoi oblasti posluhamy (u 1996 - 2018 rr.) [Dynamics of the geographical structure of foreign trade in Dnipropetrovsk region by services (in 1996-2018)]. Retrieved from http://dneprstat.gov.ua/ statinfo\%202015/zed/2018/zed8.pdf [in Ukrainian].

6. Statystychnyi zbirnyk "Rehiony Ukrainy" [Statistical collection "Regions of Ukraine”]. (2014). Part 2. Retrieved from https://ukrstat.org/uk/druk/publicat/Arhiv_u/Arch_reg.htm [in Ukrainian]. 


\section{Матвесва Ольга Юріївна}

Кандидат наук 3 державного управління, доцент Дніпропетровський регіональний інститут державного управління Національної академії державного управління при Президентові України 49044, м. Дніпро, вул. Гоголя, 29

Email: olivebox30@gmail.com

\section{Шевченко Лілія Гранитівна}

Кандидат економічних наук, доцент

Дніпропетровський регіональний інститут державного управління Національної академії державного управління при Президентові України 49044, м. Дніпро, вул. Гоголя, 29

Email: shev4enko.lilia1@gmail.com

\section{Matveieva Olga}

Ph.D. of Public Administration, Assoc. Prof.

Dnipropetrovsk regional institute for public administration National academy for public administration under the President of Ukraine 29, Gogol Str., Dnipro, 49044, Ukraine

ORCID: 0000-0003-3344-1497

\section{Shevchenko Lilia}

Ph.D. of Economic Sciences, Assoc. Prof.

Dnipropetrovsk regional institute for public administration National academy for public administration under the President of Ukraine 29, Gogol Str., Dnipro, 49044, Ukraine

ORCID: 0000-0002-4853-8593

Цитування: Матвеєва О. Ю. Аналіз стану та тенденцій розвитку зовнішньої торгівлі в Дніпропетровській області: виклики та можливості для сталого регіонального зростання / О. Ю. Матвеєва, Л. Г. Шевченко// Аспекти публічного управління. - 2019. - Т. 7 - № 9-10. - С. 79-87.

Citation: Matveieva, O.Yu. \& Shevchenko L.G. (2019). Analiz stanu ta tendentsii rozvytku zovnishnoi torhivli v Dnipropetrovskii oblasti: vyklyky ta mozhlyvosti dlia staloho rehionalnoho zrostannia [Analysis of the situation and trends in foreign trade of Dnipropetrovsk region: challenges and opportunities for the sustainable regional growth]. Public administration aspects, 7 (9-10), 79-87.

Стаття надійшла / Article arrived:29.08.2019

Схвалено до друку / Accepted: 30.09.2019 